\title{
Do Voters Support Austerity Measures in Times of Economic Crisis? For Many Voters, the Answer is Yes
}

TYLER STEELMAN | UNIVERSITY OF NORTH CAROLINA, CHAPEL HILL

| $\mathrm{n}$ the wake of the 2008 global financial crisis, governments across the world turned to economic measures designed to shore up their economies and lessen the impact on their citizens.

These measures-referred to as austerity-include policies and programs aimed at reigning in government spending or increasing income taxes with the goal of spurring economic activity.

Regardless of the economic situation being experienced by a country, austerity measures have not always been considered popular among voters. In fact, some researchers theorize that austerity measures can lead to electoral consequences for the governments that enact them. Former President of the European Commission, Jean-Calude Junker, once commented that politicians knew austerity was necessary but that politicians "... just don't know how to get re-elected after we've done it."

Kirk Bansak, Michael M. Bechtel, and Yotam Margalit enter this debate with their new APSR article: "Why Austerity? The Mass Politics of a Contested Policy." The authors show that austerity measures are actually popular among most votersbut only when certain provisions are included. In general, voters

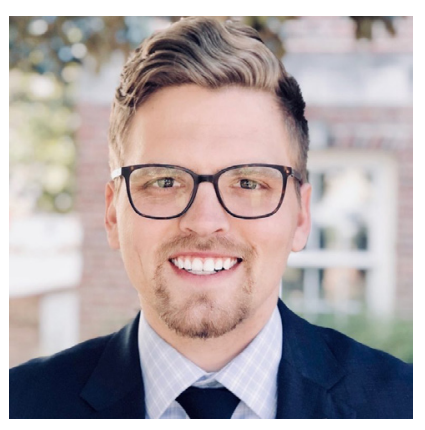
are supportive of governments enacting austerity measures, but this support can be diminished when increased income taxes or decreased pension benefits are on the table.

Research on the popularity of austerity is varied. For some, the politics of austerity revolve around the economic merits of

Tyler Steelman is a PhD candidate in American Politics and Political Psychology at the University of North Carolina at Chapel Hill. His research focus includes the study of surrogate representation and the development of legislative districts using ZIP codes in the United States. His work has been published in the Election Law Journal, Interest Groups and Advocacy, and The Monkey Cage.

In the APSA Public Scholarship Program, graduate students in political science produce summaries of new research in the American Political Science Review. This piece, written by Tyler Steelman, covers the article "Why Austerity? The Mass Politics of a Contested Policy" by Kirk Bansak, Michael M. Bechtel, and Yotam Margalit. The full article is available at: https://doi. org/10.1017/S0003055420001136. the situation. Those in support of austerity argue that slashing government spending is necessary to increase confidence that the country's deficit is under control. Critics of austerity believe that governments should increase spending in the form of economic stimulus in an effort to increase spending among citizens.

Others, though, see austerity through the lens of political feasibility-or whether government programs will be popular with voters. Here, policies like increasing taxes and cutting government spending are thought to decrease support for the government in power. In turn, the practice of passing austerity measures can be seen as both economically and politically perilous.

Using survey data from five European countries-Italy, Spain, France, Greece, and the United Kingdom-in 2015 and 2019, Bansak, Bechtel, and Margalit find that a large majority of voters favor austerity. By asking voters in these five countries to indicate whether they approved of cutting back government spending to spur the economy, the authors discover that support ranges from a simple majority to more than $75 \%$ of voters in France. Going further, support for austerity even extends to far left voters (who are thought to be less supportive) in every country except the United Kingdom. These findings shed new light onto the debate over public support for austerity measures and demonstrates that members of the public are, generally, supportive.

But the authors do not stop there. They also examine how governments might structure an austerity plan to minimize potential electoral backlash. By using a conjoint experiment-a tool that allows the researchers to understand which aspects of an austerity plan are preferred by voters and which are not-some measures are found to be more popular than others. For example, in Italy and Spain, voters are more likely to support plans that cut spending to the military or public sector jobs; voters are less likely to support plans when they include cuts to pensions and increases to income taxes.

The debate surrounding the topic of austerity is unlikely to go away anytime soon. As countries across the world continue to grapple with the financial impacts of COVID-19 and the economic aftermath of shutting down entire sectors of their economy, governments will likely be making decisions about whether to cut spending, raise taxes, or both. Bansak, Bechtel, and Margalit show that public support for these measures may be popular-under the right circumstances. 